\title{
SPIRIT OF NOAH : MEMAKNAI ULANG SEMANGAT KENABIAN DALAM ALKITAB MELALUI KARYA SENI RUPA
}

\author{
Theresia Agustina Sitompul \\ Fakultas Seni Rupa dan Desain ISI Surakarta \\ theresiasitompul1005@gmail.com
}

\begin{abstract}
In the legend of Noah's Ark, God punished one whole generation of Noah who were wicked and defying God by sending a natural disaster in the form of the Great Flood, destroying the nature. Noah was commanded to build an ark (medium) to save himself, his family, and his followers, also all kind of animals in pairs; to save a generation of life that later will create a new civilization and culture in a new area or location. The legend of Noah's Ark can be found in almost every holy book of divine religions where the story conveys the message of a lifecycle and how we learn about the meaning of life.

Associating the story with our current lives, Noah's Ark has two concepts of interpretation; in the context of salvation and at the same time as a mediation space of the birth of a new culture. How human save themselves from their worldly problems, and at the same time a mediation space, a shifting space from the old culture into the new culture. These two concepts of Noah's Ark are the background and the base this creation for the writer.
\end{abstract}

Keywords : Spirit of Noah, graphic art, hermeneutika.

\begin{abstract}
ABSTRAK
Dalam kisah Bahtera Nuh, Tuhan akan menghukum satu generasi Nuh yang jahat dan menentang kuasaNya dengan menurunkan bencana alam berupa air bah, yang berakibat pada rusaknya alam (nature) pada saat itu. Nuh diperintahkan untuk membuat sebuah bahtera (media) untuk menyelamatkan diri, keluarga dan umatnya, serta para binatang yang berpasangan dari segala jenis, menyelamatkan satu generasi kehidupan untuk nantinya menciptakan sebuah peradaban dan kebudayaan baru dalam wilayah atau lokasi yang baru pula. Kisah Nuh ini ditemukan di hampir semua risalah agama Samawi di mana kisah ini menjadi sebuah risalah akan siklus kehidupan dan bagaimana kita belajar untuk memaknai hidup.

Mengasosiasikan dengan kisah Nuh dengan kondisi kehidupan kita saat ini, sesungguhnya Bahtera Nuh mempunyai dua konsepsi penafsiran, yakni adalah konteks penyelamatan sekaligus sebagai sebuah ruang mediasi lahirnya kebudayaan baru. Bagaimana manusia menyelamatkan diri mereka atas segala permasalahan dunia mereka, sekaligus ruang mediasi ruang perpindahan dari budaya lama menjadi budaya baru. Dua konsepsi dari kisah Bahtera Nuh inilah yang menjadi latar belakang penciptaan penulis.
\end{abstract}

Kata-kata kunci : Bahtera Nuh, penyelamatan, ruang mediasi, seni grafis 


\section{PENDAHULUAN}

\section{A. Latar Belakang}

Kisah-kisah yang terdapat dalam Alkitab banyak yang dijadikan inspirasi dalam proses kreatif penciptaan karya seni. Teks-teks dalam Alkitab berupa susunan tulisan membentuk jaringan konseptual dan struktur makna yang dapat ditafsirkan. Dalam Alkitab terdapat kisah-kisah yang berasal dari tuturan kemudian ditulis menjadi teksteks yang menjadi rujukan dan dasar bagi setiap pemeluk agama untuk menjalani kehidupan keberagaman. Sumber-sumber dalam Alkitab yang berasal dari kehidupan manusia ribuan tahun yang lalu tentu saja mempunyai peluang untuk dimaknai ulang disesuaikan dengan konteks masyarakat yang juga terus berubah.

Proses menafsirkan ayat-ayat dalam Alkitab menjadi bentuk-bentuk yang bermakna tentu tidak bisa dilakukan secara semena-mena. Penulis yang mempunyai latar belakang pendidikan seni grafis memberikan tawaran penafsiran terhadap salah satu kisah dalam Alkitab yaitu tentang Bahtera Nuh melalui penciptaan karya seni grafis.

Kisah tentang Bahtera Nuh adalah salah satu kisah yang ba- nyak termuat dalam berbagai risalah agama Abrahamik (Yahudi, Kristen, Katolik, Islam). Dalam agama Nasrani, pada Kitab Kejadian 6:14-9:29 dikisahkan latar belakang Tu-han mengirimkan air bah, hingga menyuruh Nuh untuk membuat bahtera demi keluarga dan para binatang hingga dijelaskan secara mendetail bagaimana tahun-tahun terakhir Nuh setelah meredanya air bah. (Eksposisi Kitab Kejadian, Kejadian 6:14-9:29, Air Bah : 125).

Epos Gilgames adalah salah satu kisah Babilonia yang mempunyai kesamaan dengan Kitab Kejadian dimana banjir muncul karena kekuasaan Mahi untuk mengingatkan manusia akan dosa-dosa yang mereka perbuat, dan sang pemeran utama selamat beserta dengan seluruh keluarganya. (Eksposisi Kitab Kejadian, Kejadian 6:14-9:29, Air Bah : 125. Utnapistym dalam Epos Gilgames tentang air bah).

Dalam Islam juga di kisahkan tentang risalah Nabi Nuh yang diperintahkan untuk mengingatkan kaumnya agar menyembah Allah yang saat itu menganut paganisme dengan menyembah berhala-berhala Suwa', Yaghuts, Ya'uq, dan Nashr. Dalam Al-Qur'an, Nuh diperintah selama 950 tahun. Rujukan-rujukannya tentang Nuh dalam 
al-Qur'an bertebaran di seluruh kitab. Surah dalam al-Qur'an yang cukup lengkap menceritakan kisah Nuh adalah surat Hud dari ayat 27 hingga 51. (Al-Qur'an Terjemahan. Penerbit Departemen Agama RI).

Cerita-cerita tentang air bah ter-sebar luas dalam mitologi dunia, dengan contoh-contoh praktis dari setiap masyarakat. Padanan Nuh dalam mitologi Yunani adalah Deucalion, Dalam teks-teks India sebuah banjir yang mengerikan dikisahkan telah meninggalkan hanya satu orang yang selamat, yaitu seorang suci yang bernama Manu yang diselamatkan oleh Wisnu dalam bentuk seekor ikan, dan dalam. Zoroastrian tokoh Yima menyelamatkan sisa-sisa umat manusia dari kehancuran oleh es. Cerita-cerita air bah telah ditemukan pula dalam berbagia mitologi dari banyak bangsa prasejarah dari wilayah-wilayah yang jauh dari Mesopotamia dan benua Eurasia; salah sate contohnya adalah legenda orang-orang Indian Chippewa. (www.wikipedia. com/bahteranuh).

Beragam kisah tentang Bahtera Nuh mempunyai banyak periwayatan dan penafsiran dimana di dalamnya mencampurkan solusisolusi teoritis dengan masalahmasalah praktis seminal bagaimana cara Nuh membuang kotoran-kotoran binatang, atau dengan penafsiran-penafsiran alegoris yang mengajak manusia menuju jalan keselamatan dengan mematuhi perintah Tuhan. Konsepsi tentang penyelamatan inilah yang kemudian dipahami sebagai konsepsi dominan dari kisah Bahtera Nuh ini.

Penafsiran konsepsi tentang penyelamatan ini pula yang banyak menginspirasi para seniman untuk pada era Kekristenan awal mengangkat kisah Nuh dalam karyakaryanya. Mereka seringkali menggambarkan Nuh yang berdiri di sebuah kotak yang kecil di tengahtengah gelombang, yang menggambarkan tentang Allah yang menyelamatkan Gereja sementara melalui gelombang pergumulan. Penafsiran ini seringkali dinisbatkan pada Perjanjian Baru (1 Petrus 3:20-21), menyatakan bahwa perdamaian bagi mereka yang ada di Bahtera melalui air bah memberikan gambaran awal tentang orang Kristen yang diselamatkan melalui pembaptisan. (Kitab Perjanjian Baru).

Dalam proses penciptaan karya ini, penulis banyak terinspirasi oleh beragam karya seni sebelumnya yang memuat tema maupun konsepsi-konsepsi dari kisah Bahtera Nuh. Adapun beberapa karya yang 
menginspirasi seniman diantaranya adalah beragam bentuk visualisasi Bahtera Nuh yang selama ini telah dicoba untuk diinterpretasi ataupun visualkan dalam beragam bentuk karya seni. Sebagai contoh karya Amrus Natalsya Perahu Nabi Nuh, karya Cornelius Van Drebbel, The First Submarine, karya Anusapati, Preserve vs Exploit, dan lain sebagainya. Kesemuanya menjadi dasar dalam melakukan kajian konseptual maupun visual sebagai bahan masukan sekaligus pertimbangan dalam mengolah bentuk visual karya.

Kisah riwayat nabi Nuh dalam Alkitab menceritakan bagaimana Tuhan mendatangkan banjir yang dahsyat bagi manusia, sebagai sebuah peringatan akan kelalaian mereka dari penyembahan terhadap Tuhannya. Nuh diperintahkan untuk membuat sebuah bahtera untuk menyelamatkan diri dan umatnya, dengan seluruh bangsa binatang yang berpasang-pasangan. Saat musibah air bah itu datang, para manusia yang menentang Nuh dan Tuhannya, menjadi korban kedahsyatan banjir dan selamatlah Nuh dan umatnya dari bencana tersebut.

Namun, memahami lebih jauh penafsiran tentang konsepsi penye- lamatan dalam Bahtera Nuh dari berbagai macam kaidah penafsiran Al Kitab, sesungguhnya kisah tentang Bahtera Nuh ini merupakan gambaran akan realitas perubahan peradaban manusia yang disertai dengan perubahan paradigma kebudayaannya. Konsepsi perubahan kebudayaan dapat kita pahami sebagai sebuah siklus, dimana perubahan yang terjadi pada nature/ alam baik karena bencana alam ataupun peperangan, sesungguhnya akan berakibat pada perubahan kebudayaan masyarakatnya. Ketika alam beserta kehidupan manusia hancur dan rusak karena bencana maka akan hancur pula peradaban kebudayaannya. Sebagaimana hancurnya kota Pompeii karena letusan Gunung Vesuvius, atau bencana dingin yang berkepanjangan yang terjadi di Amerika karena tertutupnya bumi oleh debu vulkanik letusan Gunung Tambora di Sumbawa tahun 1815. (Eksposisi Kitab Kejadian).

Mengasosiasikan dengan kisah Nuh, sesungguhnya Bahtera Nuh mempunyai dua konsepsi penafsiran, yakni adalah konteks penyelamatan sekaligus sebagai sebuah ruang mediasi lahirnya kebudayaan baru (atau proses reproduksi kebudayaan). Proses penciptaan karya 
seni grafis dalam jurnal ini akan difokuskan pada tafsir semangat kisah Nabi Nuh pada konteks masyarakat sekarang yang juga membutuhkan penyelamatan dari kerakusan yang menyebabkan kerusakan lingkungan. Selain itu juga membangun pengharapan akan kehidupan masa depan yang lebih baik setelah manusia memperoleh penyelamatan yang diperantarai oleh adanya kesadaran terhadap pentingnya menjaga dan melestarikan lingkungan hidup. Dua konsepsi dari tafsir semangat kisah Bahtera Nuh inilah yang menjadi latar belakang sekaligus landasan dalam penciptaan karya yang berjudul Spirit of Noah.

Penulis menggunakan pendekatan hermeneutika dalam menafsirkan semangat dari Bahtera Nuh ke dalam bentuk karya seni grafis. Selain itu, penulis juga meminjam konsep metafora.

\section{B. Rumusan Masalah}

Bagaimana menciptakan karya seni grafis yang didasari oleh semangat dan spirit kisah Bahtera Nuh berdasarkan kisah dalam Alkitab ?

\section{Landasan Penciptaan}

Sebagai landasan dan pijakan teoretik dalam merumuskan gagas- an konseptual maupun gagasan visual, maka penulis menyandarkan proses kreatif yang akan dijalani berdasarkan pada perkembangan estetika seni rupa kontemporer yang banyak berpijak pada ungkapan metafor. Sebagai bahan kajian utama, penulis menyandarkan pemahaman tentang metafor dalam proses penciptaan karya seni pada artikel jurnal Relasi Luar - Dalam Seni dan Metafora oleh M. Dwi Marianto. Metafor adalah ungkapan linguistik yang paling sering dipergunakan dalam berbagai pemakaian bahasa sehari-hari, demikian pula dalam konteks retorik dan literer.

Esensi metafor dipaparkan Philip Wheelwright (1962: 71-72), ada-lah kedalaman psikis dari dunia baik sesuatu yang real maupun unreal (fantasi), dipindahkan oleh kehebatan imajinasi dan kepiawaian teknik kreatif seseorang. Proses transmutatif yang dilibatkan dapat dideskripsikan sebagai semantic motion (gerakan atau perubahan semantik) yang merupakan ide utama secara implisit dalam kata metafor.

Seringkali kita mempergunakan metode berfikir deduktif (berfikir teoritikal dulu, baru melihat fenomenanya), bukan sebaliknya me- 
lihat, mengamati, menangkap persoalan esensial dari suatu fenomena tertentu baru kemudian dicari pendekatan teori yang tepat untuk pengolahan dan perolehan sebuah analisa de-ngan cara pandang yang berbeda.

Proses penciptaan dan karya seni melulu diletakkan sebagai objek kajian intelektual semata, atau hanya dikaji dengan pendekatanpendekatan logika yang bersemayam dibelahan otak kiri. Karenanya ia lebih didekati dengan teori-teori baku atau pereduksian tertentu agar dapat diterangkan sehingga pada akhirnya taksunya atau dinamikanya yang justru paling esensi tak tertangkap. Padahal teori merupakan cara pandang dengan berbagai perangkat metodis yang keabsahan ilmiahnya dipertanggung-jawabkan secara logika, intelektual, dan ilmiah.

Seabstrak - abstraknya materi subjek yang dihadirkan dalam pencitraan tertentu, yang paling imajiner dan absurditas sekalipun, secara langsung maupun tidak langsung pasti berupaya mengkomunikasikan sesuatu yang ingin dinyatakan atau diartikulasikan dengan kemasan tertentu yang lebih bersifat metaforik. Langkah operasional penting dalam proses penciptaan seni adalah se- rangkaian kemampuan seseorang dalam memetik salah satu momenmomen estetik tertentu yang mengalir kemudian ditransform pada karya riil.

Metafor bukan sekedar bentuk semantik tertentu, melainkan merupakan karakter fundamental hubungan linguistik manusia dengan dunia. Linguistikalitas manusia sudah semantiasa bersifat metaforais. Matra tidaklah berlebihan bila dikatakan bahwa metafor memiliki kekuatan untuk menata ulang persepsi kita, dan mengorganisasikannya secara baru, mengejutkan namun sekaligus pula memuaskan sebab cocok dengan pengalaman dan menyiratkan kenyataan. Namun metafor juga bukanlah sekadar cara untuk mengatakan sesuatu dengan kata, yaitu untuk mengubah cara kita berada dan melihat realitas. Makna sebuah metafor mengatasi dirinya sendiri dan membimbing kita ke sesuatu yang justru tidak dikatakannya.

Dalam konteks proses kreatif, sebuah metafor sejatinya adalah peranti vital yang tak dapat ditawartawar dalam penggalian gagasannya sebagai pembuka pintu ruang imajiner sampai pada pengolahan perenungan untuk menyeleksi berbagai kemungkinan pemakaian ba- 
hasa metafor yang ingin di presentasikan ke orang lain. Pengolahan dasar -ide dasar- sebuah metafor sangat bergantung pada tingkat kecerdasan dan kematangan kepekaan estetika tiap individu, termasuk keterampilan menggunakan dan mengolah bahasa ekspresi yang tentu secara teknis dan alasan teknis berbeda. Meskipun demikian metafor tetap saja sangat berjasa pada bagaimana ruang imajiner lebih terbuka.

Bermain metafor berarti menciptakan sesuatu secara kreatif, membutuhkan kemampuan berpikir biasosiatif dan keberanian mengeksplorasi berbagai kemungkinan dari hal-hal yang kasat mata, virtual, dan imajiner dalam pola berpikir lateral. Bagi praktisi seni, kesadaran akan peran utama metafor dan pemahaman berbagai piranti pembentukan metafor secara kreatif, fasih, dan produktif tanpa diganggu dengan kewajiban-kewajiban untuk merumuskan karya seni tanpa beban filsafati.

Hal ini dapat diartikan bahan ketika seseorang melakukan aktivitas kesenian dengan sendirinya ia telah melakukan 'metaphor' karena seseorang kreator dalam berpikir, dalam penggalian gagasan sampai pada eksekusi mengaktualkan ke dalam bahasa ekspresi dengan measosiasikan dua hal sejenis atau berbeda untuk merepresentasikan gagasannya dengan metaphor-metafor.

Maka berpijak dari pemahaman inilah penulis melandaskan proses penciptaan karya yang akan dilakukan dengan mencoba mengelaborasikan konsep metaphor sebagai 'pintu masuk' dalam menciptakan sebuah karya.

Sebagai bahan pendukung kajian dalam landasan penciptaan ini, penulis juga melakukan pembacaan pada kajian linguistic turn sebagai pendukung dalam memahami konteks metafor sekaligus sebagai bahan perbandingan bagaimana metafor beroperasi dalam pro -ses penciptaan karya seni.

\section{Metode Penciptaan}

Dalam proses penciptaan karya, penulis melalui tahapan-tahapan dimulai dari merumuskan ide dan gagasan konseptual, mencari bentuk-bentuk visual yang dapat mewakili ide dan gagasan, serta yang terakhir adalah eksekusi visual dalam wujud karya seni. Karya-karya (tersebut) bersumber dari teks berupa kisah Bahtera Nuh yang tertera dalam Kitab Kejadian 6:14-9:29 dikisahkan Tuhan yang mengirim- 
kan air bah untuk memberi hokuman kepada manusia yang tidak beriman dan menyuruh Nuh sebagai salah satu utusan Tuhan untuk membuat bahtera demi keluarga dan para binatang agar selamat dari banjir besar yang akan menenggelamkan mereka. Dalam Alkitab juga dijelaskan secara mendetail bagaimana tahun-tahun terakhir Nuh setelah meredanya air bah serta bagaimana Nuh membuat bahtera atau kapal. (Al Kitab terbitan mana tahun kapan?)

Kisah Bahtera Nuh tersebut sudah penulis akrabi dan baca sejak kecil sebagai bagian dari upaya penulis untuk memahami iman kristiani penulis. Teks dalam Alkitab yang berisi kisah-kisah tersebut sangat imajinatif, inspiratif, dan menjadi salah satu stimulan bagi penulis untuk membuat karya seni. Penulis membangun imajinasi berdasarkan pengalaman hidup penulis yang kompleks. Dari kompleksitas pengalaman hidup tersebut, penulis menyarikan melalui proses reflektif (memikirkan dan merasakan), melakukan seleksi dan memilih peristiwa-peristiwa yang relevan dan bermakna bagi penciptaan karya seni penulis. Selain itu, penulis juga membuka diri terhadap terang kehadiran objek diluar diri penulis yang juga memperkaya imajinasi dan kreativitas penulis. Penulis, percaya bahwa tidak ada yang betul-betul baru di dunia ini sehingga dalam proses penciptaan karya, penulis berusaha untuk mengungkapkan diri dengan tulus, tanpa pretensi dalam berkomunikasi, berinteraksi dengan objek di luar diri penulis dan menjadikannya sebagai bagian dari proses penciptaan karya seni penulis. Proses tersebut ternyata mampu menghasilkan metafor-metafor yang dapat mewakili ide dan gagasan awal penulis mengenai kisah Bahtera Nuh.

Eksekusi visual dalam bentuk karya seni adalah dengan menghadirkan objek berupa kapal dari kayu dengan konstruksi tertentu di dalamnya berisi biji-bijian. Bagi penulis biji-bijian tersebut mewakili konsep harapan akan tumbuhnya generasi masa depan yang diselamatkan oleh Bahtera Nuh. Generasi inilah yang akan memimpin dunia di masa depan. Objek yang lain adalah anak-anak sebagai simbol dari generasi baru. Selain itu penulis juga menghadirkan pelampung untuk mewakili konsep dari penyelamatan. Pemilihan bentuk, gaya, dan teknik penciptaan akan penulis paparkan pada bab selanjutnya.

Penciptaan seni terjadi oleh 
adanya dorongan cipta, rasa dan karsa yang dimiliki oleh seseorang, karya seni hadir berkat adanya upaya seniman untuk mengekspresikan gagasannya yang didasari adanya kreativitas dan apresiasi yang kuat. Dalam alur tahapan proses kreatif L.H Chapman yang termuat dalam bukunya Approaches to Art in Education (1978) ada beberapa tahapan penting dalam sebuah proses kreatif seorang perupa. Prosesproses itu diantaranya adalah :

1. Tahap penemuan gagasan (inception of an idea), atau mencari sumber gagasan, ide, inspirasi ataupun ilham. Proses mencari gagasan merupakan upaya seniman untuk mendapatkan creative impulse. Hal ini bukan saja sebuah kesengajaan semata, namun unsur-unsur ketidaksengajaan juga mem -pengaruhi seniman untuk merespon setiap apa yang di temui.

2. Tahap penyempurnaan, pengkembangan dan pemantapan gagasan (elaboration and refinement). Tahap ini merupakan proses pengembangan gagasan menjadi ide pravisual yang nantinya mempunyai kemungkinan untuk diwujudkan dalam bentuk kongkret.

3. Tahap visualisasi karya ke me- dium yang akan digunakan. Pada tahap proses visualisasi karya ini pemilihan media menjadi sangat penting bagi seorang perupa dalam menuangkan gagasannya. Keterampilan mengolah media berikut pemahaman terhadap media yang akan digunakan menjadi tolak ukur "ke -berhasilan" sebuah karya.

Pada tahap ide dilakukan penggalian informasi dan referensi dari berbagai sumber literatur seperti Alkitab, buku, majalah, internet dan lain-lain, mengenai tema terkait. Pada tahapan perancangan karya, hasil eksplorasi terhadap sumber ide ditransformasikan dalam beragam bentuk sketsa alternatif. Sketsa terbaik dipilih untuk kemudian diwujudkan dalam karya Seni Grafis dengan menggunakan teknik Litografi Plat aluminium.

Perkembangan Lithografi berbasis plat logam di Amerika mulai terihat pada kisaran pertengahan abad ke 20 yakni tahun 1930-an oleh beberapa seniman. Pada awalnya konsentrasi pengembangan cetak litografi mereka berbasis pada $\mathrm{Li}$ mestone (batu gamping), namun hal ini tidak berlangsung 
lama dikarenakan kelangkaan media. Untuk mengatasi hal ter -sebut maka digunakan plat logam sebagai pengganti Limestone. Hal yang sama juga terjadi pada beberapa praktek seni grafis di belahan Eropa. Mereka memanfaatkan plat logam sebagai pengganti batu Limestone yang mulai langka, berikut alasan politik dimana, mekanisme berikut bahan yang digunakan dikuasai oleh manufaktur percetakan yang banyak berkembang pada waktu itu. Proses perlakuan media (plat logam) di beberapa negara sangat beragam, hal ini lebih banyak disesuaikan dengan ketersediaan bahan berikut proses manufakturnya.

\section{PEMBAHASAN}

\section{A. Proses Penciptaan Karya} Seni Grafis Noah's Ark

Pada perkembangan seni grafis di Indonesia, teknik Lithografi sa-ngat jarang digunakan. Hal ini disebabkan karena keterbatasan media limestone. Sebagaimana perkembangan seni grafis di berbagai negara, usaha pengembangan media telah banyak diupayakan, namun hasil yang diperoleh masih sangat signifikan. Untuk itu, dengan berbagai ekperimentasi yang telah dilakukan, penulis telah mengembangkan sebuah metode lithografi berbasis plat alumunium yang akan digunakan sebagai dasar penciptaan karya.

Beberapa karya penulis dengan teknik litografi plat alumunium:

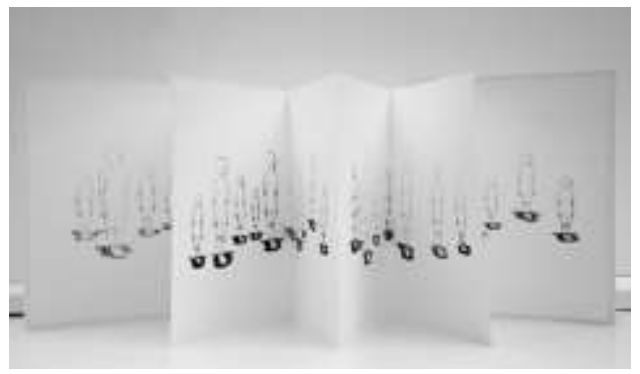

\section{Gambar 01.}

Theresia Agustina S, Next Generation, 2011, Lithografi plat alumunium di kertas canson valin de arches $250 \mathrm{gr}, 31 \times 248 \mathrm{~cm}$ (dokumentasi: Silviana)

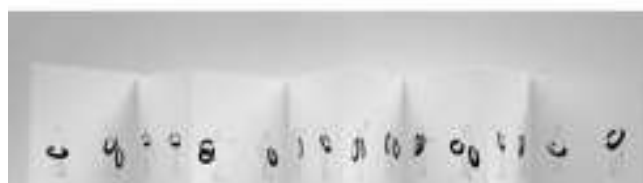

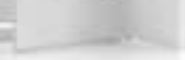

\section{Gambar 02.}

Theresia Agustina S, Safety First Kid, 2011, Litografi plat aluminium di kertas canson valin de arches $250 \mathrm{gr} 31$ x $248 \mathrm{~cm}$ (dokumentasi : Silviana)

Spirit penyelamatan sebagaimana yang diambil dari konsep gagasan tentang Bahtera Nuh (yang telah dijelaskan dalam pendahuluan diatas), diwujudkan dalam sketsa rancangan dalam bentuk 3 dimensi dan selanjutnya dibuat dalam karya 
dengan teknik seni grafis. Gagasan formal (kebentukan) dalam karya ini terinspirasi dari bentuk kapal selam yang pertama kali, dengan beberapa perubahan bentuk dan elemen visual lainnya.

Persiapan dalam proses penciptaan karya seni merupakan faktor yang penting. Sebelum proses perwujudan dimulai kita perlu mempersiapkan bahan, alat yang digunakan dalam mendukung pembuatan karya meggunakan teknik lithografi plat aluminium.

\section{Bahan-bahan}

1.1 Plat Alumunium

1.2 Amplas/Kertas Gosok

\subsection{Busa Spon}

1.4 Sarung Tangan Karet

1.5 Bedak/ Baby Powder

1.6 Arabic Gum

1.7 Terpentin

1.8 Pensil, Pensil Mekanik

1.9 Dermathograph /Pensil kaca

\subsection{Kuas}

\subsection{Sikat Gigi}

1.12 Crayon Litho

\subsection{Aspaltum}

1.14 Roll

1.15 Tinta Cetak (Charbonel)

2. Tahapan teknik Lithografi plat aluminium:

2.1 Siapkan plat alumunium, potong sesuai ukuran yang diinginkan (maksimal lebih kecil dari mesin press yang ada).

2.2 Siapkan amplas. Lalu amplas permukaan plat menggunakan amplas manual atau amplas elektrik. Mengapa plat harusdi amplas? Fungsinya adalah untuk menghilangkan lemak dari permukaan plat. Ciri-ciri plat bebas lemak adalah plat menjadi berwarna abu-abu dan kasar.

2.3 Siapkan arabic gum. Beri arabic gum pada kuas atau spon lalu oleskan pada sisi atau pinggiran plat, agar plat aman dari lemak tangan. Sifat arabic gum adalah menolak lemak, karena plat bersifat sensitif terhadap lemak.

2.4 Siapkan bahan-bahan yang mengandung lemak. Seperti: terpentin, dermatograph (pensil kaca), karbon, pensil, pensil mekanik, crayon litho dan asplatum. Masing-masing bahan yang digunakan mempunyai karakter yang berbeda-beda.

2.5 Plat aluminium yang sudah siap/ selesai diproses lalu digambar menggunakan bahan - bahan yang berlemak.

3. Proses melapisi plat dengan Arabic gum. 
3.1.Siapkan Arabic gum. Campurkan air dan Arabic gum pada bak yang sudah tersedia dengan perbandingan 1:20 (1 arabic gum : 20 air)

4. Proses Penintaan dan Mencetak

4.1 Siapkan kaca, rol dan tinta

4.2 Sebelum tinta dipindahkan pada plat dengan menggunakan rol, basahi dulu plat dengan menggunakan spon.

\subsection{Pastikan tinta yang tidak} dikendaki lepas dari plat dengan cara dihapus/dilap menggunakan spon dan air bersih

4.5 Siapkan mesin press dalam keadaan bersih

4.6 Letakkan plat pada mesin press 4.7Ambil kertas kering dan letakkan diatas plat yang akan dicetak.

\section{B. Deskripsi Karya}

Pada bagian ini penulis akan memaparkan mengenai deskripsi karya seni grafis yang berjudul Noah's Ark. Karya seni grafis ini merupakan interpretasi penulis dari kisah Bahtera Nuh yang tertera dalam Kitab Kejadian 6:14-9:29. Dikisahkan Tuhan yang mengirimkan air bah untuk memberi hokuman kepada manusia yang tidak beriman dan menyuruh Nuh sebagai salah satu utusan Tuhan untuk membuat bahtera demi keluarga dan para binatang agar selamat dari banjir besar yang akan menenggelamkan mereka. Dalam Alkitab juga dijelaskan secara mendetail bagaimana tahun-tahun terakhir Nuh setelah meredanya air bah serta bagaimana Nuh membuat bahtera atau kapal. (Al Kitab terbitan mana tahun kapan ?)

Berdasarkan kisah tersebut penulis membuat karya grafis yang berjudul Noah's Ark (Bahtera Nuh). Karya tersebut terdiri dari beberapa elemen karya seni grafis, di antaranya :

\section{Karya 1}
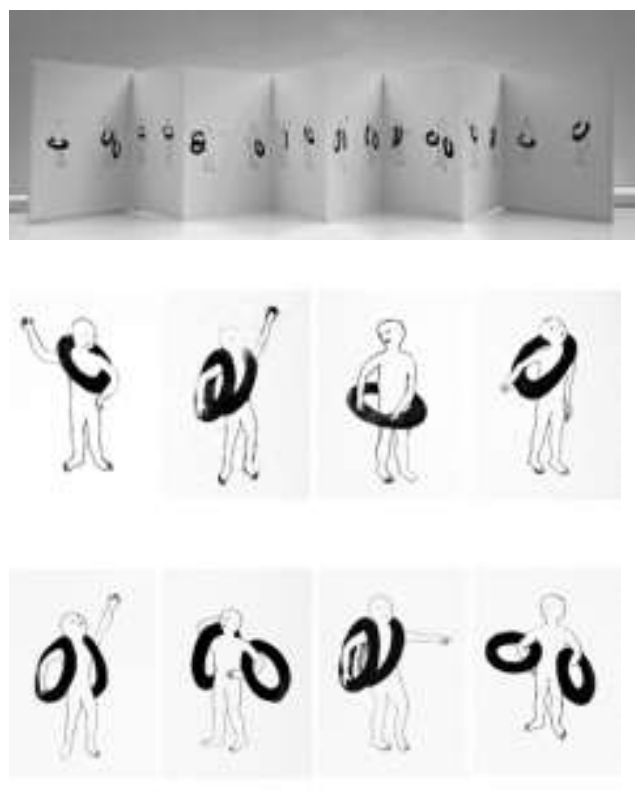

Gambar 03.

Theresia Agustina S, Safety First Kid\#01, 2011. Lithografi plat aluminium di kertas canson valin de arches $25 \mathrm{gr}, 31 \times 248 \mathrm{~cm}$. (Dokumentasi: Silviana) 
Karya di atas berupa figur ma nusia membawa pelampung dengan berbagai gaya. Ini pelesetan dari safety first kit. Sebagai mana esensi dan konsepsi penyelamatan yang diangkat dari kisah bahtera Nuh, maka dalam karya ini penulis meyakinkan bahwa pada dasarnya setiap orang mempunyai bahtera untuk penyelamatan diri mereka.

Manusia mempunyai sistem pertahanan dalam dirinya untuk bergerak dan tetap hidup menjaga diri dan kehidupannya. Bahtera Nuh merupakan tamsil Tuhan bahwa bagaimanapun kehidupan yang dihadapi manusia, ia harus tetap berpegang kepada dirinya sendiri dan Tuhannya. Malalui karya ini, penulis ingin mengungkapkan bahwa dalam kondisi apapun sesungguhnya tiap individu mempunyai kesadaran diri untuk bertindak demi kelangsungan hidupnya. Contohnya dalam orang modern, mulai membuat atau membangun rumahnya dengan sistem untuk mengantisipasi jika terjadi gempa misalnya, mereka membangun dengan menggunakan sistem rumah dengan struktur untuk gempa. Berikut himbauan untuk menjaga kelangsungan hidup dan menyiapkan (menyelamatkan) bumi ini untuk kehidupan generasi mendatang yang lebih baik.
Karya 2
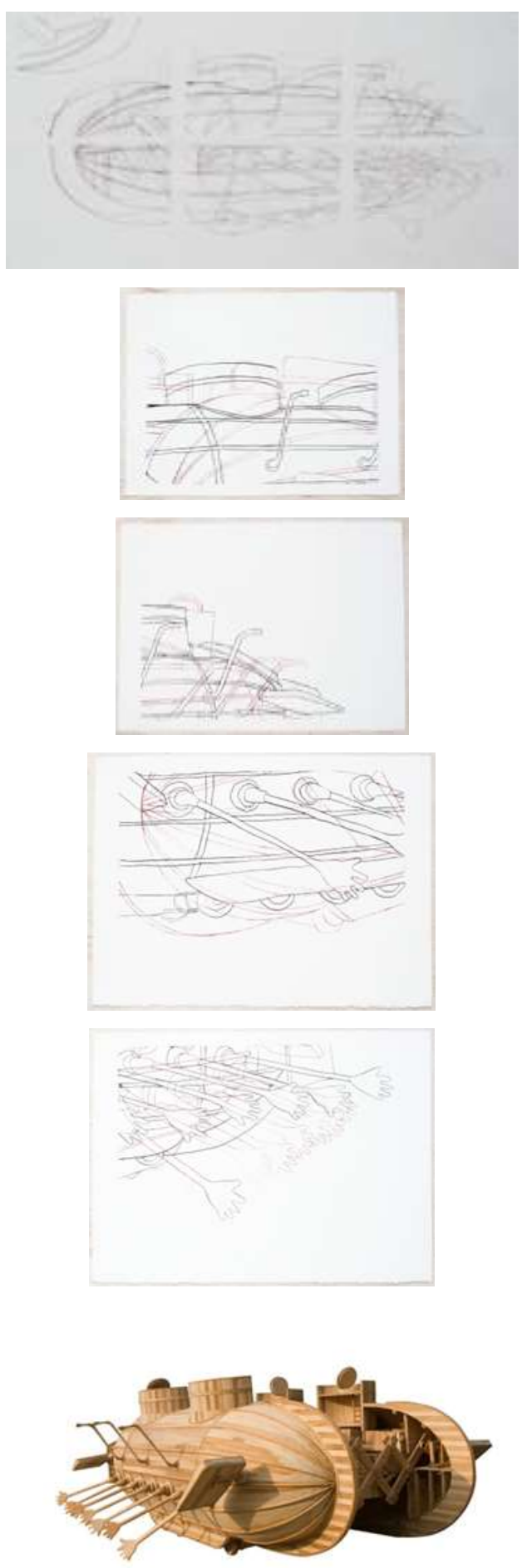

\section{Gambar 04}

Theresia Agustina S, Noah's ark, 2011. Lithografi plat aluminium di kertas canson valin de arches $250 \mathrm{gr}, 100 \times 200 \mathrm{~cm}$ (dokumentasi: Danang ) 
Karya yang berjudul Noah's Ark di atas berupa bahtera atau kapal besar berbentuk kapsul, dengan dayung berbentuk jari-jari tangan, periskop yang digunakan untuk melihat kedalam kapal. Di dalam kapal terdapat kotak-kotak yang berisi biji-bijian. Karya tersebut dibuat di gambar menggunakan teknik seni grafis dan kemudian di buat dalam bentuk tiga dimensi.

Konsepsi bahtera dalam Alkitab, dimana Nabi Nuh mengisi kapalnya dengan sepasang makhluk hidup (konsepsi penyelamatan). Namun dalam kapal yang berbentuk kapsul seperti kapal selam ini, berisi bermacam-macam biji-bijian. Sebuah ide penyelamatan untuk hutan dan pohon bisa dibayangkan bagaimana kepunahan hutan mengancam kita, atau kita yang mengancam kepunahan hutan itu sendiri.

\section{Karya 3}

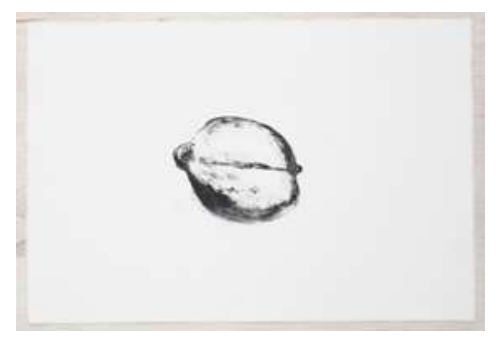

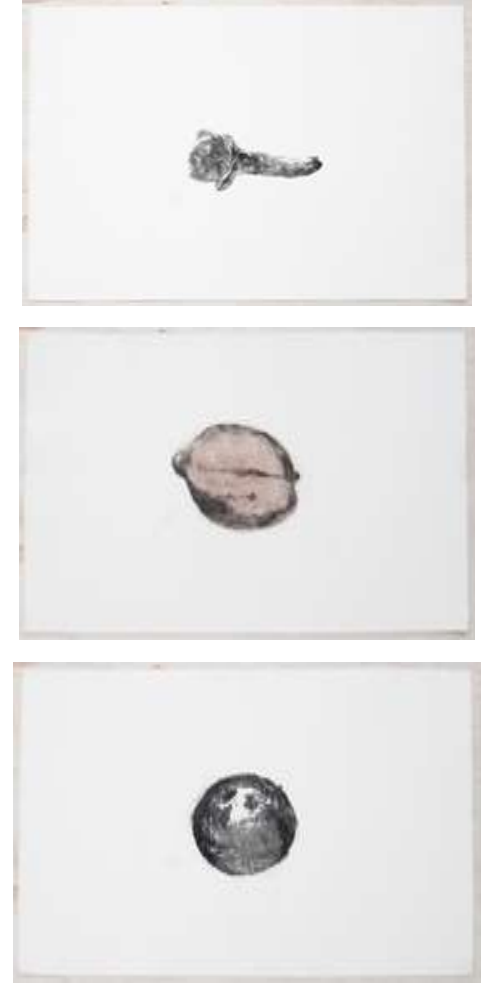

\section{Gambar 05}

Theresia Agustina S, Save the Savior \#02, 2011. Lithografi plat aluminium di kertas canson valin de arches 250gr, @56 x 38 $\mathrm{cm}$, (dokumentasi: Danang )

Pada karya di atas terdapat berbagai macam biji-bijian yang di gambar ulang dan diwujudkan dalam karya seni grafis. Karya yang berjudul Save the Savior menggambarkan bahwa biji-bijian sebagai 'pelampung hidup'. Biji-bijian yang diambil dari biji pohon keras, biji untuk jamu atau obat, biji untuk bumbu, biji untuk bahan pokok. Biji dan akhirnya menjadi pohon. Pohon adalah salah satu yang menolong dan memberi harapan untuk hidup. Jika manusia ingin menyelamatkan bumi dan manusia sendiri tentunya 
harus menyelamatkan penyelamatnya dulu. Dalam konsepsi bahtera di Alkitab, dimana Nabi Nuh mengisi kapalnya dengan sepasang makhluk hidup (konsepsi penyelamatan). Namun dalam karya ini kapal yang berbentuk kapsul seperti kapal selam ini, berisi bermacam-macam biji-bijian. Sebuah ide penyelamatan untuk hutan dan pohon bisa dibayangkan bagaimana kepunahan hutan mengancam kita, atau kita yang mengancam kepunahan hutan itu sendiri.

\section{SIMPULAN}

Teks-teks dalam Alkitab mengenai Kisah Bahtera Nuh mempunyai relevansi dengan kondisi kehidupan manusia di muka bumi saat ini. Sebagai sebuah teks, kisah Bahtera Nuh terbuka untuk ditafsirkan sesuai dengan konteks masyarakat. Penulis kemudian membuat karya-karya yang berangkat dari upaya untuk memberi tafsiran terhadap Kisah Bahtera Nuh dalam Alkitab. Meskipun tema-tema tersebut telah banyak dikerjakan oleh jutaan seniman di seluruh dunia, penulis dengan menggunakan imajinasi dan kreativitas mampu mencari celah untuk menghasilkan bentukbentuk artistik yang khas.

Tafsir atas semangat kisah
Bahtera Nuh dalam karya-karya penulis berkaitan dengan konteks penyelamatan sekaligus pengharapan akan masa depan dunia baru yang lebih baik. Tafsir ini mewujud dalam bentuk karya yang mengambil metafora kapal dan anak-anak. Kedua objek tersebut hadir secara dominan dalam karya-karya penulis. Dalam menafsirkan teks Alkitab, penulis menggunakan teori hermeneutika, sedangkan dalam menciptakan karya penulis menggunakan metafora. Hal ini dapat diartikan ketika seseorang melakukan aktivitas kesenian dengan sendirinya ia telah melakukan metafor karena seorang kreator dalam berpikir, dalam penggalian gagasan sampai pada eksekusi mengaktualkan ke dalam bahasa ekspresi dengan mengasosiasikan dua hal sejenis atau berbeda untuk merepresentasikan gagasannya dengan metafor-metafor.

Situasi seperti yang tersirat pada cerita Nabi Nuh adalah sebuah tema yang mencerminkan harapan. Sebuah sikap optimis; setelah kehancuran akan dunia baru yang lebih baik seperti dijanjikan Tuhan. Jadi intinya adalah kebangkitan dari "kematian". Kiamat bukan akhir dari segala-galanya tapi awal dari sebuah dunia baru. Bencana alam yang terjadi belakangan ini 
membuat kondisi para penghuni di bumi menjadi panik. Setiap manusia berusaha menyelamatkan dengan membangun sistem penyelamatan terhadap dirinya. Kondisi yang ada pada saat ini adalah manusia di bumi mulai tidak merawat dan melindungi alam sekitarnya. Manusia semakin mengeksploitasi apa yang ada di bumi.

Kisah itu ada bukan hanya di Al Quran, tetapi juga di Taurat dan Injil. Konon Tuhan murka karena ajaran Nuh tidak diterima oleh orang-orang di sekitarnya. Kemudian Tuhan mengutus Nuh untuk membuat sebuah kapal besar, yang di dalamnya selain diisi oleh manusia, juga dengan berbagai jenis binatang. Tuhan hendak mengirim bah untuk menghukum manusia yang tidak mau menerima ajarannya. Kapal pun jadi, bah pun terkirim. Nuh membuat sebuah peradaban dengan manusia-manusia di kapalnya beserta hewan-hewan yang turut serta. Peristiwa itu konon, sekali lagi konon, terjadi pada 3650 tahun SM.

Maka melalui karya-karya seni grafis, pada Spirit of Noah penyelamatan dalam bahtera Nuh diambil penulis dalam menciptakan karya tersebut. Bentuk kapal selam dengan dayung-dayung berkepala ta- ngan manusia merupakan simbolisasi dari upaya penyelamatan. Bentuk kapal dideformasi dengan penambahan beberapa elemen visual agar lebih artistik dan menjauhi kesan duplikasi semata. Di dalamnya penulis menambahkan beberapa elemen biji-bijian / benih tumbuhan atau bibit tanaman di dalamnya, sebagai simbolisasi regenerasi dan bagian kehidupan yang harus diselamatkan. Periskop disematkan sebagai alat untuk melihat benihbenih didalam kapal tersebut sekaligus sebagai perlambangan agar manusia melihat emapati dan kepedulian dalam dirinya. Melalui karya ini penulis ingin memberi tawaran penafsiran terhadap teksteks Alkitab terutama kisah Bahtera Nuh dalam bentuk karya seni. Penulis percaya kekuatan karya seni tidak sekedar menggambarkan realitas tetapi akan dapat menjangkau esensi dari realitas itu sendiri. Dengan demikian, diharapkan mampu menumbuhkan kesadaran manusia tentang ancaman akibat perusakan lingkungan hidup yang akan berpengaruh pada generasi masa depan serta kesadaran untuk menyelamatkan kehidupan dan eksistensi manusia di muka bumi. 


\section{DAFTAR PUSTAKA}

Chapman, L. H. (1978), Approach to Art in Education, Harcourt Brace Jovanovich, San Diego.

Feldman, Edmund Burke. (1967), Art As Image and Idea, The University Of Georgia, USA.

Hughes, Ann D'Arcy dan Hebe Vernon Morris. (2008), The Printmaking Bible. Chronicle Books LLC, USA.

Honour, Hugh dan J. Fleming. (1995), A World History Of Art, Tanpa keterangan penerbit.

Haryatmoko. (2000), "Hermeneutika Paul Ricoeur: Transparansi Sebagai Proses", dalam Majalah BASIS, No. 05-06, tahun ke-49, Mei-Juni, Kanisius, Yogyakarta.

Kellner, Douglas. (1994), Baudrillard Reader, Blackwell, Cambridge.

Marianto, M. Dwi. (2002), Seni Kritik Seni, Lembaga Penelitian ISI Yogyakarta, Yogyakarta.

Marianto, M. Dwi. (2007), "Artikel Relasi Luar-Dalam Seni dan Metafora", dalam Jurnal Surya Seni, Vol. 3. No.1, BP ISI Yogyakarta, Yogyakarta.

Piliang, Yasraf Amir. (1998), Sebuah Dunia Yang Dilipat: Realitas Kebudayaan Menjelang Millenium Ketiga dan Matinya Posmodernisme, Mizan, Bandung.

. (2003), Hipersemiotika, Tafsir Cultural Studies Atas Matinya Makna, Penerbit Jalasutra, Yogyakarta.

Strinati, Dominic. (1995), An Introduction to Theories of Popular Culture, Routledge, London.
Ensiklopedia :

Encyclopedia Encarta. (2009), Microsoft Encarta @ 2009. @ 19932008 Microsoft Corporation. All rights reserved./ Printmaking/ Lithograph/Planograf. 